事業参加世帯からみた震災復興共同建替事業の評価に関する研究

一公団による震災復興共同建替事業を対象にして一

\title{
A STUDY ON THE RESIDENTS' EVALUATION OF THE JOINT HOUSING PROJECT AFTER HANSIN-AWAJI EARTHQUAKE \\ -A case of project provided by Urban Development Corporation-
}

田中貢*, 碓田智子**

Mitsugu TANAKA and Tomoko USUDA

\begin{abstract}
The purpose of this paper is to examine the residents' characteristics and their evaluation of the joint housing project after Hansin-Awaji earthquake. We researched 7 condominiums. They were the joint housing projects provided by Urban Development Corporation-. We analyzed 102 documents of residents and questioned to 123.households of their evaluation for the joint housing project by questionnaires. The results of this paper are as follows.

1) Many residents were aged small family and they couldn't afford to get their houses. They couldn't build their new houses by themselves because their land didn't accommodate to the law . 2) Participating in the joint housing project, $70 \%$ of residents could keep the community which they had before the earthquake. $72 \%$ of residents are satisfied with the joint housing project, but they aren't satisfied enough with their houses. 3) We found that residents who got enough floor space by exchanging their land were satisfied with the joint housing project.
\end{abstract}

Keywords : the Joint Housing Project after Hanshin-Awaji Earthquakes, Residents' Characteristics, Residents' Evaluation 震災復興共同建替事業、居住者特性、居住者評価

\section{1.はじめに}

阪神・淡路大震災で大きな被害を受けた密集市街地では、生活道 路が狭小、接道不良、土地の権利関係が輻輇するなどの理由で、居 住者個人の力では住宅再建にかかわる課題の解決が困難であった。 仮に課題が解決できたとしても低質な住宅の再生産となり、建物も 地区環境も低質となる可能性があったため、住宅復興の一手法とし て、住民参加による共同建替事業が取り組まれた。その結果、阪神 地区で 80 件あまり注1)というかつてないほど大量の共同建替によ る住宅再建が、比較的短期間に実現した。共同建替事業による住宅 は、震災後 $3 \sim 5$ 年を経て建設されたケースが多い。震災から 10 年を経た現在では、入居後数年が経過して、ようやく居住者の生活 が落ち着いた状態に戻り、また暮らしてみて気づく様々な課題が見 えてくる時期と考えられる。

本研究は、住宅・都市整備公団 (以下、公団。現在、都市再生機 構）の事業を対象として、阪神・淡路大震災の住宅復興で取り組ま れた共同建替事業を、居住者が落ち着いた生活を取り戻した現段階 で、事業参加世帯の視点から事業の検証を試みるものである。本稿 では、1）事業参加世帯の当時の収入状況、家族特性、入居に至る
プロセス、資産の緒条件を検討することによって、当事業がどのよ うな世帯層に住宅を供給できたのかを明らかにする。また、2）事 業参加世帯の共同建替事業に対する評価の検討を通じて、震災復興 共同建替事業が果たした役割および課題を事業参加世帯の側から考 察する。さらに、3）共同建替事例レベルの資産条件、建物条件お よび立地条件などの地区の差異が、事業参加世帯の事業に対する評 価にどうつながったのかについても検討を加える注2)。

\section{2. 本研究に関連する既往研究}

本研究の対象である震災復興共同建替事業に関しては、事業段階に 応じて、いくつかの既往研究が行われている。

まず、震災復興共同建替事業のプロセスの初期段階においては、ま ちづくり組織等への調查から、専門家やまちづくり組織が住民閒の合 意形成や事業促進化に大きな役割を果たしたことが導きだされてい る文献2）3）4）5）6）。また、共同建替事業と居住地改善や区画整理事業 との関係については、小規模な共同建替を連鎖することで住民の居住 環境の大きな変化を伴わずに地区環境改善を図ることが可能である と論じた研究文献7)、狭小敷地を使った共同建替の課題解決に区画整理
* 大阪府都市整備推進センターまちづくり事業部 学修

** 大阪教育大学教育学部 助教授. 博士 (学術)
Osaka Prefectural Urban Improvement Center, M.A.

Assoc. Prof., Faculty of Education, Osaka Kyoiku Univ., Ph. D. 
事業の有効性があったことを明らかにした研究文触8)、区画整理事業進 捗に行政と住民をつなぐ専門家の役割が大きいことを示した研究文献 9)がみられる。

震災復興共同建替事業後においては、地域や住棟レベルでのコミュ. ニティ再生に注目した研究がある。事業参加者へのヒアリング等によ り、コミュニティの形成要因を抽出し、共同建替の事業プロセスの各 段階で、建替計画の工夫など各種のコミュニティづくりの仕掛けが必 要であること文献 10)、また当時の共同建替組合代表者へのアンケート 調查により、専門家と行政、まちづくり協議会の関与がコミュニティ 形成に貢献していることを検証している文椾 11)。法的関係や住宅施策 の視点では、震災復興の事例から既成密集市街地の改善策として共同 建替事業の应大を推奖する研究がなされている文㪍 12) 13）14（15）16）17)。 さらに、震災復興を総合的に検討した一連の研究では、従来の法定都 市計画・事業からより柔軟で多様な都市計画・事業へのパラダイム転 換が必要であるとして、震災復興事業の教訓をもとに、我が国の都市 に存在する膨大な木造密集市街地の改善のために柔軟な都市計画・事 業の必要性や有効性を示唆している文触18)。

以上のように、震災復興の共同建替事業に関する既往研究では、 事業実現プロセスおよび事業後の居住者のコミュニティ形成に専門 家やまちづくり組織等のかかわりが重要であったことに加えて、こ の事業が地域環境の改善に有効であったことが明らかにされている。 しかしながら、震災復興共同建替事業が結果的には、どのような世 帯層に住宅を供給したのか、また事業参加世帯が事業をどう評価し

表17地区の居住世带的奋の配覃·回収状況

\begin{tabular}{|c|c|c|c|c|c|}
\hline 地区名 & 入居時期 & $\begin{array}{r}\text { 対象 } \\
\begin{array}{|}\text { 户数 } \\
\text { A }\end{array}\end{array}$ & $\begin{array}{c}\text { 配票 } \\
\text { 数 }\end{array}$ & $\begin{array}{c}\text { 回収 } \\
\text { 票数 } \\
\text { B }\end{array}$ & $\begin{array}{l}\text { 回 収 率 } \\
(\%) \\
\text { A/B }\end{array}$ \\
\hline A地区(長田区) & $H 10.12$ & 25 & 23 & 21 & 84.0 \\
\hline B 地区(長田区) & $H 11.12$ & 10 & 9 & 9 & 90.0 \\
\hline C地区(長田区) & $H 12.03$ & 21 & 20 & 18 & 85.6 \\
\hline D地区(兵庫区) & $H 11.04$ & 40 & 40 & 37 & 92.5 \\
\hline E地区(西宮市) & $H 12.01$ & 39 & 39 & 28 & 71.8 \\
\hline F地区(中央区) & $H 11.06$ & 3 & 3 & 3 & 100.0 \\
\hline G地区(灘区) & $\mathrm{H} 11.02$ & 11 & 11 & 7 & 63.6 \\
\hline 合 計 & & 149 & 145 & 123 & 82.6 \\
\hline
\end{tabular}

注；F地区は、他に 14 戸が公営住宅部分になっている

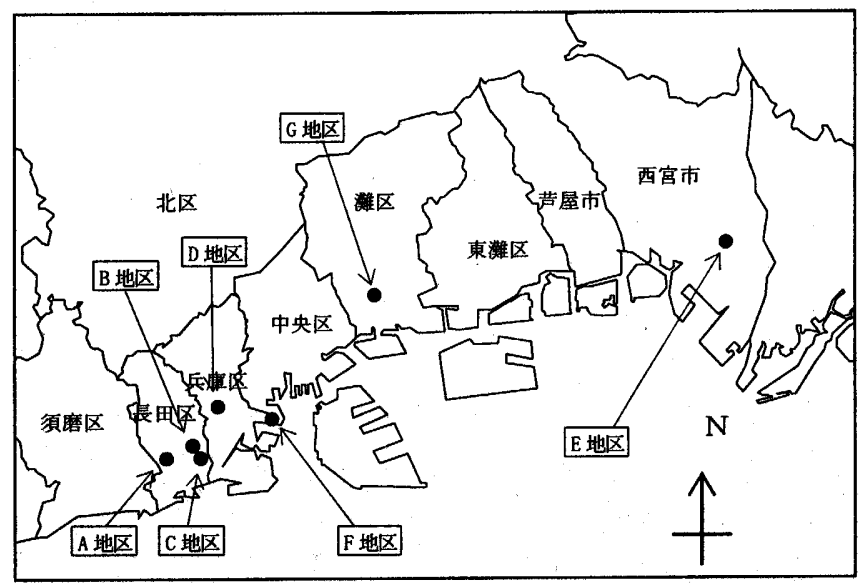

图17地区の位雷
ているのかなど、事業参加世带に直接團ねた研究はほとんど行われ ていない。また、震災復興共同建替事業参加世帯の事業参加による 凟産の変化についても検討を加えた研究は、筆者の知りうる範囲で は兒られない。

\section{3. 研究の方法}

\section{3-1 対象地区について}

震災復興共同建替事業の事例として、公団が事業主体で取り組ん だ震災復興共同建替住宅 23 地区のうち、1 世帯で 1 住戸の所有を基 本とし、事業参加世帯自身が入居した事例を取り上げ、神戸市西部 地域から阪神間の西宮に至る区域内の 7 地区を調查対象とした（表 1、図 1 )。これらは戸数が 40 戸までの比較的小規模な事業である。

これら 7 地区周辺は、震災前はすべて必集市街地の中にあった。 うち 5 地区 (A〜E) は、土地区画整理事業の集約換地により事業が 実現したものである。震災前から長田区など神戸市中央地域より西 部の地域は、分譲住宅の需要動向が芳しくなく、共同建替事業によ り生まれた余剩の保留床についてもその処分が危ぶまれ、住宅処分 を受け持つ住宅会社にも事業参画を躊躇された経過を持った地域で ある。一方、阪神間の事業地はバブル崩壊後の地価下落に伴う都心 回帰の波に押され、余剩床についても処分が予定通り進み事業收支 が組み立て易かった地域で、人口回復も早かっだ注 3)。本研究で神 戸市西部から阪神間の事例地を取り上げたのは、立地の違いよる地 区の差異が居住世帯の事業評価にどう関連しているかを検討課題の 一つにしたからである。

\section{3-2 調查方法}

本研究では、前述の 7 地区の震災復興共同建替事業を対象に以下 に示す、(1)事業参加申し込み書、(2)居住世帯を対象としたアンケー 卜調查、(3)設計図等事業計画書のデータを用いて検討を進めた。 まず事業組み立ての当初段階から震災復興共同建替事業に参加し た 7 地区 102 世帯注4) について、入居の約 1 年半前の事業着手前に 提出された公団への事業参加申し込み書などの資料等を独自にデー タベース化したものを用いて、共同建替事業参加世帯の概要を把握 した。入居時期は平成 10 年 12 月〜平成 12 年 3 月であり、事業参加 申し込みから概ね 1 年〜 1 年半経過して入居している。事業参加申 し込み書には、参加世帯全員で建替組合を結成する意思を証する書 類とともに、従前の各世帯の土地面積、世帯収入、家族特性などに 関する内容が書かれている。

次に、7地区の共同建替住宅の全居住世帯を対象に行ったアンケ 一ト調查から、現居住世帯の特性および居住者の事業評価を検討し た。調查は平成 16 年 8 月〜 9 月に実施した。原則として直接配票・ 直接回収によって行い、回収率は約 $83 \%$ であった。調查票の主な項 目は、事業参加世帯の現在の家族状況のほか、設計への関わりの具 合、事業参加の満足度など、参加世帯の意識にかかわる内容である。

さらに、7 地区の事業参加世帯で構成された建替組合から、それ ぞれ公団へ提出された事業計画書から共同建替住宅の建物にかかわ るデータを抽出し、地区環境も含めて現地踏查で確認して整理した。 この建物の諸条件が、各地区の事業評価にどう関与しているのかを 検討する。 


\section{4. 参加申込畫による共同建替事業参加世帯の特性}

\section{4-1 申し込み当時の事業参加世帯の世帯特性}

事業参加申し込み畫によると、参加時の 7 地区 102 世帯の平均家 族人数は 2.6 人で、 2 人までの世帯が $57 \%$ を占め、小規模世帯が多 い。単身および夫婦のみの世带が $36 \%$ を占めたほか、片親と末婚子 からなる世帯が $24 \%$ と多いことが特色であった。また、世帯主の平 均年齢は 56.9 歳で、世帯主が 60 歳以上の世帯が $49 \%$ を占め、高椧 の小規模世帯が多い。高齢世帯が多いことに関連して、年金を主た る収入とする世帯が $35 \%$ を占めた。平均世帯収入は約 550 万円であ り、600 万円未満の世帯が全体の約 $2 / 3$ であった。総じて、事業参 加世帯の多くは高齢の小規模世帯であり、年金世帯の割合が高いな ど、経済的に余裕がある階層ではなかったとみられる。

また事業参加世帯の震災前住宅は、63\%が戸建または長屋建の持 ち家 (土地は借地を含む) であり、分譲マンションが $14 \%$ あっあた。 現住宅と同じ地域からの入居世帯が 97\%を占めた。

\section{4-2 事業参加世帯の資産と負担額について}

公団による震災復興共同建替事業は、事業参加者が従前資産を提 供し、それに見合った完成後の建物床を無償で受け取るという等価 交換方式で行われた。より広い建物床を希望する場合は、追加負担 額を支払うことにより、追加床を購入する方式であった。なお、震 災によって建物が堿失していたため、従前凟産の評価は土地資産の みで行われた。

事業参加世帯のうち、従前資産の等価交換を利用した世帯は全体 の $75 \%$ (76 世帯) であり 注5)、76 世帯の従前土地資産 ${ }^{\text {注 }}$ ) は平均 49.2 $\mathrm{m}^{2}$ で、 $50 \mathrm{~m}^{2}$ 末満の小規模宅地が $72 \%$ を占めた（図 2)。従前土地資 産の等価交換をべースにして事業参加世帯が取得した共同建替住宅 の住戸面積は平均 $71.2 \mathrm{~m}^{2} て ゙ 、 50 \mathrm{~m}^{2} \sim 60 \mathrm{~m}^{2}$ 台と $80 \mathrm{~m}^{2}$ 台が多い(図 3)。 取得した住戸面積を家族人数別にみると、単身世帯では $60 \mathrm{~m}^{2}$ 末満が $64 \%$ を占めたが、家族人数に応じて住戸規模が大きくなる傾向がみ られた(図 4)。建築上の制約の他、入扂世帯間での調整が必要だっ た関係で、住戸面積の選択には少なからず制約があったが、概ね家 族規模に応じた住宅を確保できたと考えられる。

つぎに、従前土地資産を所有していた 76 世帯について、従前およ び建替後の資産を資金面から検討した。図 5 は従前土地資産額と共 同建替住宅の分誶価格の分布を、また図 6 は追加負担額と借入金の 分布を示している。地区によって地価に差異があったが、従前土地 資産額は 1500 万円未満が $71 \%$ を占めた。一方、共同建替住宅の分 譲価格帯は、2000 万円〜3000 万円台が $85 \%$ を占めた注 7 )。この従前 土地凟産額と分譲価格との差額が各世帯の追加負担額である。平均 して 1465 万円、1000 万円〜2500 万円を追加して住宅を取得した世 帯が多い注8)。また、公団の割賦による借入金の平均は 1116 万円、 1000〜2500 万円未満の世帯が 47\%を占めた。借入金がない世帯も $29 \%$ 存在するが、これは追加負担額を全て手持ちの資金で用意した ケースである。

結果としては、事業参加世帯の約 $70 \%$ が公団の割賦制度を利用し た。当時の公団事業では、割賦を組む際に年齢制限を設けず、借入 金の割賦払い年額の 4 倍の年収（年金を含む）があれば事業参加で きる仕組みになっていた。このことが高龄世帯でも事業に参加でき る機会を提供することにつながったと考えられる。
5. 現時点での事策参加の铗価について

\section{5-1 アンケート調查の回答世帯の概要}

震災復興共同建替事業では、保留床を公団が一般に分譲したこと に加えて、事業参加世帯が取得した住戸を独自に貨貸するケースが 生じたので、住宅全体としては事業参加世帶だけでなく、一般分譲 世帯、賃貸世帯の3タイプが混住する形となった。今回のアンケー 卜調査では、調查回答世帯（123 世帯）のうち、事業参加世帯は 77 世帯、一般分譔が 34 世帯、賃貸が 12 世帯である。
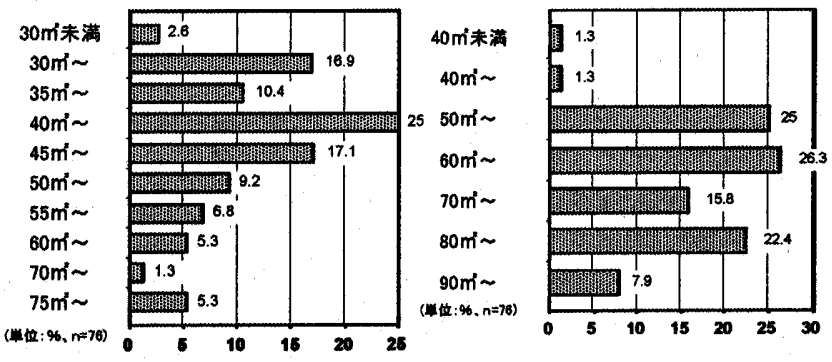

図 2 従前土地面稓

图 3 共同建替住宅の住戸面皘

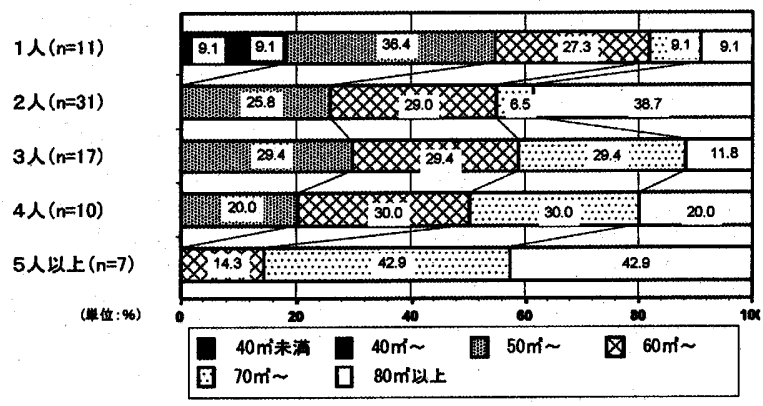

图 4 家族人数別の共同建替住宅の面皘
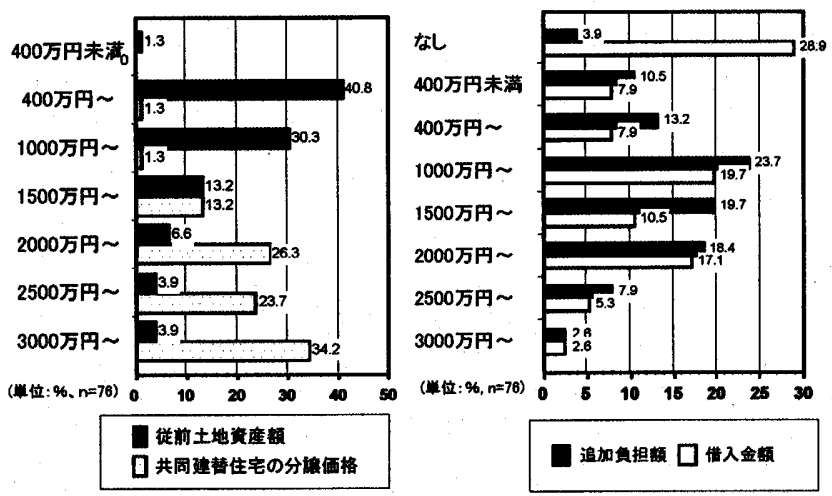

图5 従前土地资産頽と 共同建替住宅の分賠価格

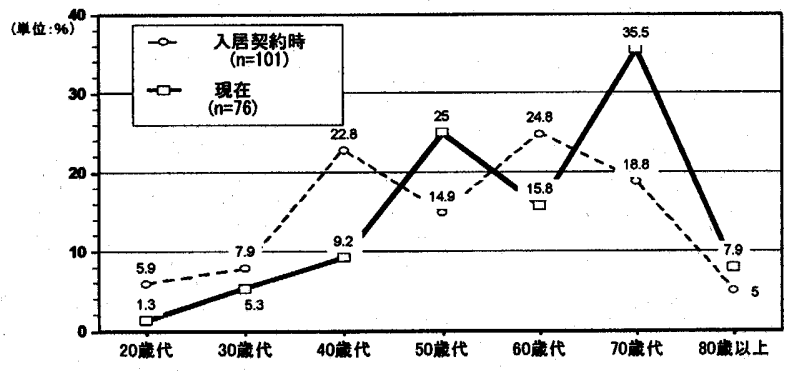

図7事業参加世带の参加時と現在の世带主年齢 
本研究で実施したアンケート調査は各地区の入居開始から $4 \sim 6$ 年経過した時点となるが、事業参加世带の平均世帯主年齢は 63.6 载で 60 歳以上の世帯が $59.2 \%$ を占めた（図 7 ）。入居契約時と比べ て世带主年齢が 6.7 藏上昇したことに加え、世带主が無職である世 柿が半数弱 $(49.3 \%)$ にのぼったことが注目された。一方、一般分 譲と貸貸世帯の世帯主年齢は 30 歳代が多く、高齢層が少ない構成に なっている(図 8)。このことから、一般分僙世帯と賃貸世帯が混住 することにより、高踴層が多い共同建替住宅に若い世帯が増え、結 果としてソーシャルミックスにつながる効果を与えたことが窥える。 なお、これ以降の分析では、事業参加にかかわる評価をみていく ため、当初からの事業参加世帯のみについて検討する。

5-2 事策参加の経緯について

アンケート調查により、事業参加世帯に事業参加直前の時点で共 同建替住宅以外の住宅を考えていたのかを尋ねた結果、48\%が別の 住宅取得の方策を考えていたことが明らかになった。共同建替住宅 以外に考えていた住宅（複数回答）は、「自己再建」が最も多く、つ いで「戸建・マンションの購入」、復興公営住宅への入居」がつづ く（図 9)。また、「自己再建」および「復興公営住宅」を回答した 世带の約 $80 \%$ は世带主が 60 歳以上の高龄世帯であった。

共同建替事業に参加した理由としては、㩤地問題で一戸建の再建 が不可能だった」が最も多かった（図 10）。事業参加世帯の多くは 密集市街地の小規模宅地所有の世帯であり、敷地の法的条件から自 己再建が事実上困難であったことが事業参加の直接的理由であった とみられる。

\section{5-3 事策参加人の満足度の検即}

先に述べたように、公団による共同建替事業は、物理的に自己再 建が困難であった世帯に自己所有住宅を地域で供給し、高齢世帯も 事業参加し易い仕組みであった。そのことを踏まえた上で事業参加 世帯が当事業や建替えた住宅をどう評価しているのか明らかにする ことが、本研究の一つの視点である。

アンケート調查では、共同建替事業への評価を、(1)事業参加への 満足度、(2)コミュニティの継続性、(3)住宅および居住地への満足度、 の 3 側面から尋ねた注9)。事業参加した 76 世帯注 10) に、総合的にみ て共同建替事業参加にして良かったかどうかを爱ねた結果では、約

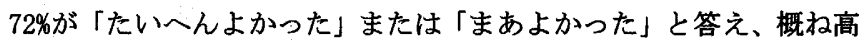
い評価がみられた（図 11）。

コミュニティの継続性に関しては、震災前からの近所付き合いの 継続軒数を尋ねてみた。事業参加世帯の $70 \%$ が同じ住宅棟内に震災 前から近所付き合いがある世帯を持っていた（図 12）。さらに、事 業参加世帯の $72 \%$ 、住宅地周辺に震災前からの近所付き合いの続 く知人を持っていた。このことから、罪災地に近いところで共同建 替事業が成立したことにより、事業参加世帯の多くが従前からのコ ミュニティを継続することができたと考えられる主11)。

現住宅と居住地に対する満足度を尋ねた結果では、居住地への満 足度に比べて住宅への満足度が低い傾向を示した（図 13）。図 14 に 示すように、住宅への満足度の高い世帯は、事業参加したことに対 しての满足度が非常に高い傾向がみられる。一方、住宅への満足度 が低い世帯は事業参加の満足度が低い。住宅について「たいんん不 満」と回答した 5 世帯のうち 3 世帯が、事業参加に対して「たい ん不満が残る」という回答をした。また、居住地への満足度と事業

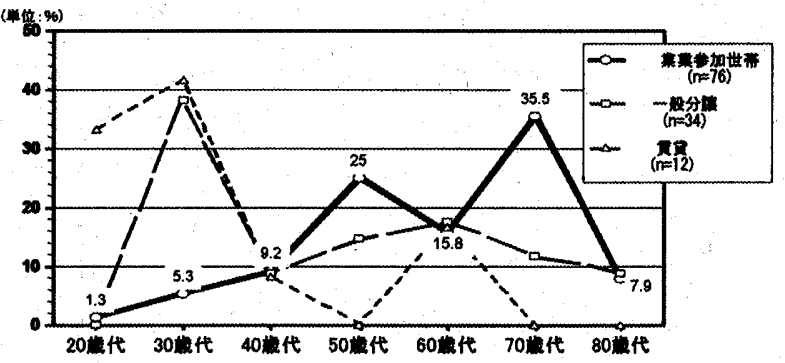

国 8 入居形式別にみた共同建替住宅居住世带の世带主年粭

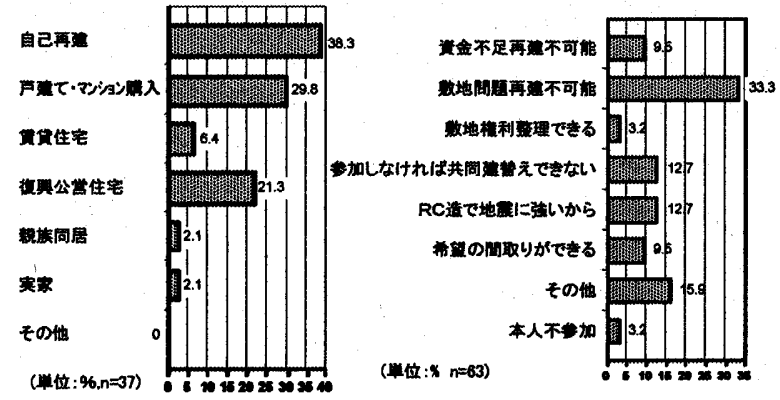

图9 共同建替住宅以外に

考えていた住宅(被数回答)

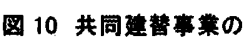
加理由(被数回答)

たいへんよかった
まあよかった
少し不满が惐る
たいへん不荡が牫る
(草位: \%,n=71)

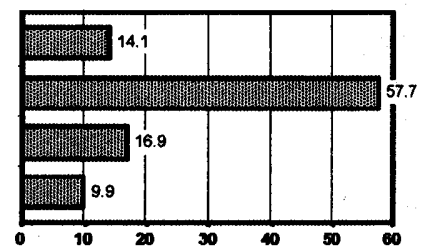

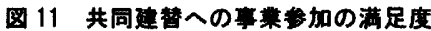

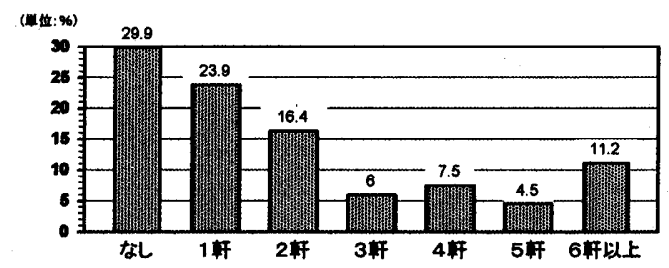

图 12 同一住宅摸内の近所付き合いの継䢂数

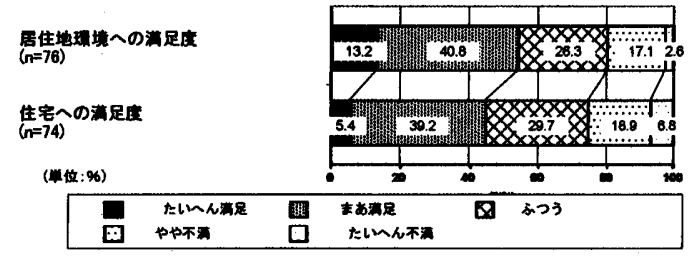

图 13 居住地理境への渾足度と住宅への满足度

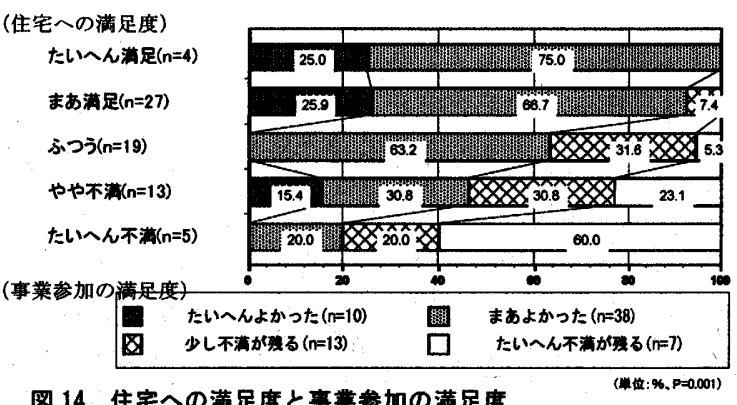

図 14 住宅への满足度と事鄴参加の满足度 
への評価の関係についても、住宅への満足度の場合とほぼ同様の傾 向がみられた注 12)。

公団の事業は、建築士と相談しながらの戸別設計方式だったが、 設計士から提案されたものを選択したと回答した世帯が事業参加世 帯の $59 \%$ を占め、設計士に任せたと回答した世帯も $15 \%$ \%った。自 分の意見どおりに設計してもらったと回答した世帯は $1 / 4$ 強の 26 \%であった。図 15 に示すように、自分の意見どおり設計してもらっ たと回答した世帯の事業参加の満足度をみると「たいんんよかった。 「まあよかった」の合計が $90 \%$ 以上なのに対し、設計士から提案さ れたものから選択したと答えた世帯では約 $60 \%$ にとどまる。また、 設計者に任せたと答えた世帯では事業に対して「不満が残る」と回 答する割合が高いことが目立つ。このように住宅設計への関わりの 程度が、共同建替事業への参加の満足度に関連していることが窥え る。

一方、将来、今の共同建替住宅に住み続ける上での不安事項を尋 ねたところ、図 16 に示すように、「高㱓者が多くなったときの維持 管理」が $58 \%$ で最も多く、ついで「体が不自由になっても住み続け られるか」が 44\%、傐齢単身になっても住み続けられるか」が $36 \%$ となっている (複数回答)。事業参加世帯には高齢世帯が多いため、 将来の生活に対する不安が少なくないようである。

\section{5-4 資産面からの検討}

従前土地資産を保有していた世帯のうち、アンケート調査に回答 を得た 66 世带について、事業参加の満足度を検討した。その結果、 図 17 に示すように、追加負担額が 2000 万円を越えると「たいんん 不満が残る」世帯がでてくる。追加負担額が 2000 万円未満では、追 加負担額にかかわらず事業参加について概ね $70 \%$ 以上が「たいいん よかった」または「まあよかった」と評価している。

追加負担額が 2000 万円未満では、追加負担額が小額であるほど事 業参加の満足度が高いというわけではない。入居後 4〜6年を経た 現段階では、追加負担額以外のことで事業を評価していると考えら れる。

震災復興共同建替事業は、事業参加世帯が事業に提供した従前土 地と、その代償として完成後に受け取る無㑽の床との交換、すなわ ち等価交換の仕組みでできている。この完成後に無償で受け取る等 価交換の床面積を従前土地面積で除した割合を、本研究では権利変 換率と呼ぶことにする。権利変換率は、従前土地の評価、保留床譲 渡価格や工事費などから決まる出来上がり床原価の影響を受ける。 事業への参加不参加の判断時に、公団から権利変換モデルが各世帯 に提示されたので、概ねどの程度の床が無償で得られ、自分が希望 する広さの床を確保するには概ね追加資金がどの程度必要かがわか る判断材料となったと思われる。図18でみるように、権利変換率と 事業参加したことの満足度の関係では、権利変換率が高いほど事業 参加の満足度（「たいへんよかった」および「まあよかった」の合計） が高くなる傾向がみられる。このことから、事業参加世帯が、事業 参加してよかったかどうかを評価する際には、等価交換で得られた 床面積の多賽、すなわち資産的に有利であったかどうかという面も 関与しているのではないかと推察される。

\section{6. 事業評洒の地区別検討}

本研究の調查対象地区は、公団として需要が得られるか不安が

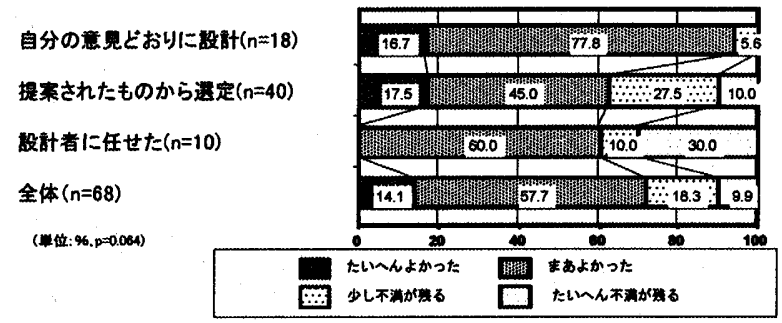

图 15 設㖕への関わりの程度と零莱加の满足度

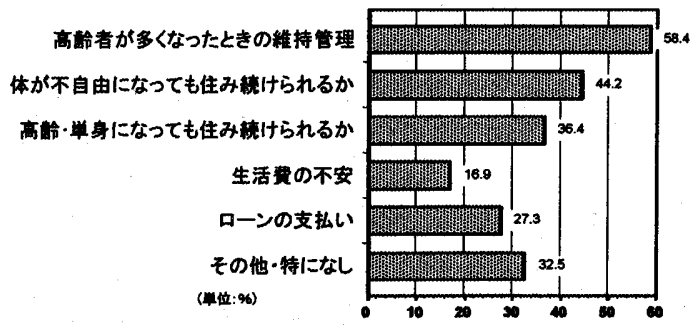

图 16 将来住み綍ける上ての不安（栕数回答）

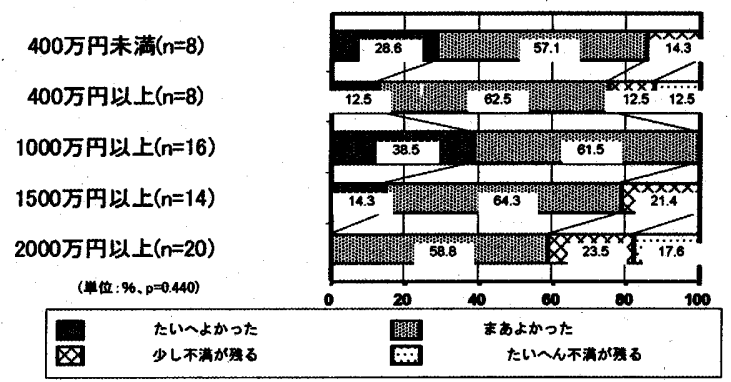

图 17 追加奂担別事莱始加の满足度

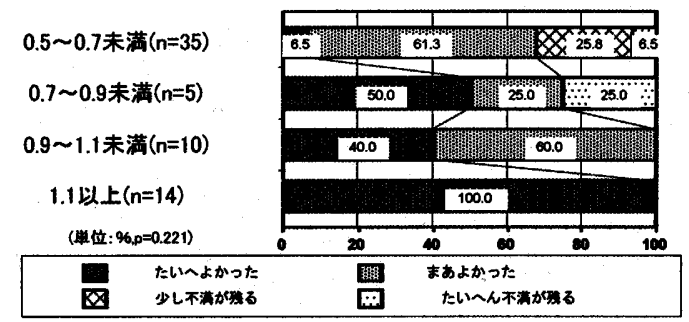

图 18 権利変換率と事菜参加の満足度

あった長田区から、需要が良好と考えられる西宮など阪神間までの 事例 5 地区である。ここでは、各地区の従前土地の評価や建勧状況 が、事業参加への満足度にどうかかわっているのかを検討する注 13)。 各地区の建物組合から提出された事業計画書等を使って、各地区に おける事業参加の満足度と建物や周辺環境等状況を整理したものが 表 2 である。なお、従前資産を持って参加した世帯が全体戸数に占 める割合が少ないFおよびG地区は、地区別の集計から除外した。 表中の事業参加の満足度は、「たいへんよかった」および「まあよか った」と回答した世帯の割合を示している。比較対象とした 5 地区 の事業参加の満足度をみると、BおよびD地区は満足度が低く、 $\mathrm{A}$ および $\mathrm{E}$ 地区の満足度が高い。以下では事業参加の満足度の数值が 際立っている地区から順に、建物概要や背景などについて検討寸る。

事業参加の満足度が最も低いD地区は、従前土地価格が 5 地区の 中で最も低く、権利変換率も低い数值となっている。この地区は、 震災前は長屋の密集地であり、震災での焼失面積が 1.5 ha と他と比 
ベて小規模だったこと、また主要な道路整備など課題が少なかった ことから、公共団体施行の区画整理が行われず、組合施行で取り組 まれた。そのため、区画整理組合の設立までの間は、何ら建築制限 がかからず、戸建住宅が無秩序に再建されることとなった。その影 響を受けて、換地後においても共同建替敷地がアメーバ状の不整形 な形状となり、接道条件の面でも、周辺環境との関係においても設 計条件が厳しかった。住戸設計においては隣接する戸建住宅の窓位 㯰なども考虑に入れながら、1 戸ずつ設計する必要が生じ、統一性 を欠く特殊な間取りの設計とならざるをえなかった。そのことが、
その後に周辺で供給された整形地に立地する民間マンションと比較 すると、デザイン上で見劣りする結果となった。凟産面で従前土地 価格と権利変換率が低かったことに加えて、敷地形状の複雑さや建 物デザインなどで見劣りする点が、事業参加の满足度が $47 \%$ と低い ことにつながったと推測される。

B地区は、戸数が 10 戸の小規模共同住宅である。共有の集会所確 保やボランティアの支援によってコミュニティ形成にも努めた稀有

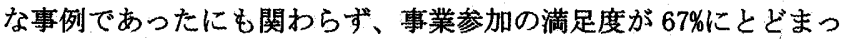
た。建物内外部の仕上げは、事業参加世帯の同意を得てコンクリー

表 2 地区別事菜解価と地区の概況

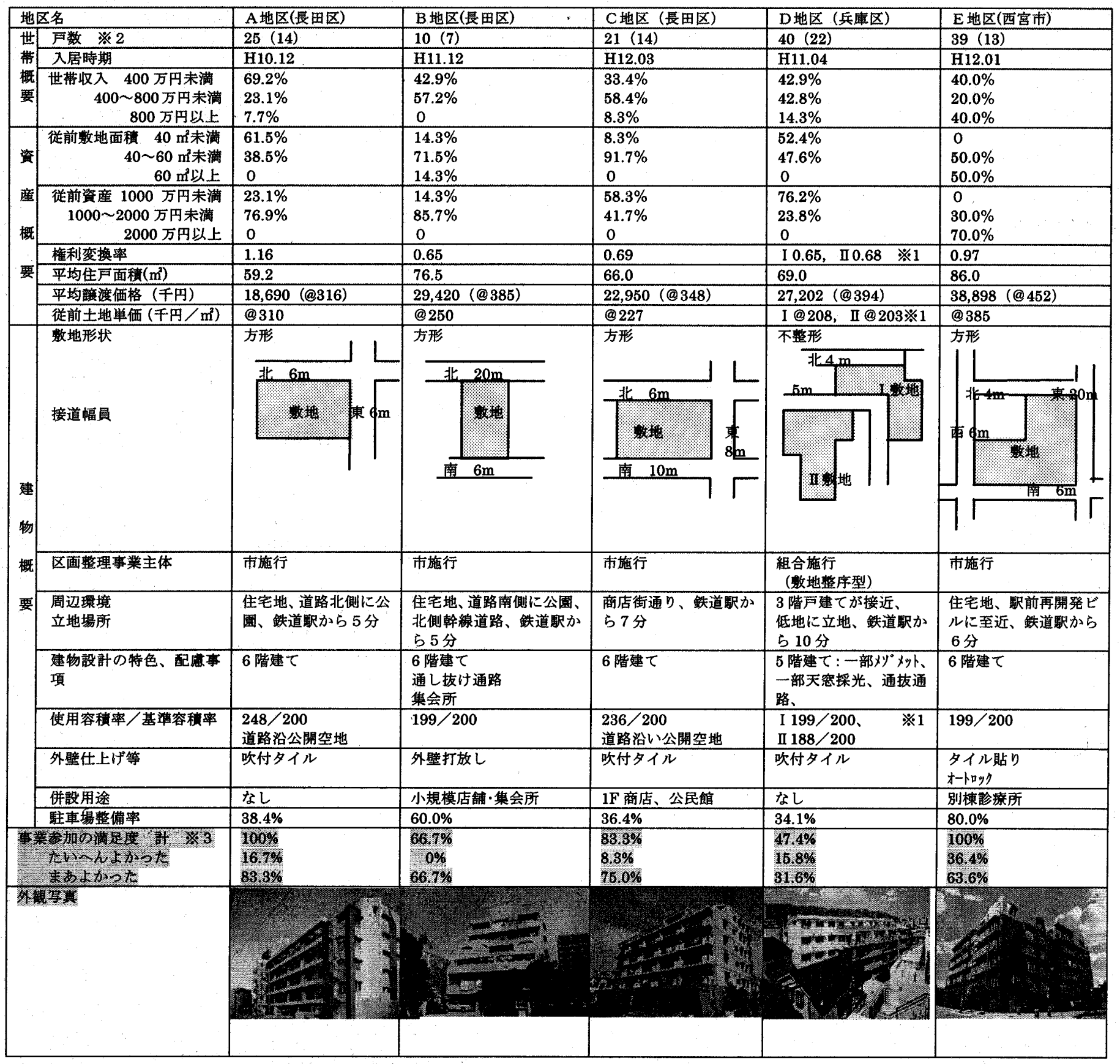

（注）※1：D地区は I・IIの 2 棟に分離しているため、権利変換率、従前土地単価、使用容積率は I と II の別に表示した。

※2：（）内は、徉前土地資産を持って事業参加した世帯数を示す

※3 : 事業参加の満足度の計は、「たいへんよかった小、「まあよかった」の\%の合計を示す。 
ト打ち放し仕上げをしたが、そのことに対して設計士と事業参加世 帯の間で認識の粗䲞が生まれ、民間マンションより住宅の仕上げが 粗雑であるという印象を与えたようである。先にあげたD地区同様 に権利変換率が低かったことに加えて、設計上の認識のズレが事業 参加の満足度の低下に関与していると思われる。

一方、事業参加の满足度が $100 \%$ と高いA地区は、世帯収入や従 前敷地面積が他地区と比較して小さく、入居した住宅も平均住戸面 積が小さい。また、僙渡価格も低いという特色を持っている。この 事例では活用容積率注 14)が高く、震災後早期の完成だったことから 保留床処分単価も高く、かつ処分の確実性が見込まれた。そのため 従前敷地面積は小さかったが、従前土地単価が高かったために、従 前資産額が高く評価されて権利変換率の上昇につながった。また、 同じ区画整理地内で最初の共同建替であったことから、事業参加者 間に相互の協力意識が強かった。設計者も地域に密着した者で、事 業参加者個々の注文に粘り強く応じた。また、同区画整理地で、遅 れて共同建替となった他事例と比較しても大幅に権利変換率が高く、 事業の有利さが後になって証明されたことなどが、建物外部仕様が 吹付タイルという演貸住宅なみの仕上げにもかかわらず事業参加の 満足度の高い評価につながったと考えられる。

同じくE地区も事業参加の満足度が $100 \%$ である。立地的には駅 前再開発地区に隣接するエリアであり、世帯収入や従前敷地面積、 従前資産額が大きい。入居した住宅も他地区よりも平均住戸面積が 大きく、譔渡価格も高い。事業参加者の従前資産額が、他地区と比 べて高く評価されたことから権利変換率が高く設定された。できあ がった住宅の平均譲渡単価が高かったが、参加世帯には世帯収入が 高い世帯が多くを占めたため負担と感じられなかったと推測される。 また、建物外壁の仕上げ程度が高いことや、駐車場整備率も他地区 に比へて格段に高いことから、事業参加の満足度が高くなったと考 えられる。

C地区は、事業参加の満足度が $83.3 \%$ である。従前は市場に続く 商店街の一角にあり、換地後も敷地は商店街に連担している。この 地区では公開空地確保により容積率アップを図ることで、従前土地 の資産性を高くしようとした。事業着手の前に地区外からの参加者 を自分たちで集め易くする算段として、保留床単価を下げたため、 権利変換率も低くなってしまった。しかし、工事着手前に全ての保 留床について入居世帯が決まり、全てが顔見知りの中で事業が進捗 したため、権利変換率が $\mathrm{B}$ や地区に近い低い数值にも関わらず、 事業参加の満足度がそこそこ高くなったと思われる。

以上のように、震災復興共同建替事業に対する評価は、個人のレ ベルだけではなく、地区レベルの権利変換率の大きさなど、地区毎 の特性による評価が関わっていると考えられる。権利変換率以外の 事業評価に関わる事柄では、(1建物外壁仕上げのグレードが高い、 (2)設計者が丁寧に戸別の住宅設計に対応した、(3)事業参加世帯が自 分たちで保留床処分したことによりコミュニティが形成された、(4) 敷地が整形で特殊な間取りが生まれなかったことなどが、地区レ心゙ ルでの事業参加の満足度が向上する要因となったと推測される。

\section{7.まとめ}

前項までの検討結果により、次の知見が得られた。

1) 事業参加世帯の参加申込書およびアンケート調查の結果から、
事業参加世带の多くは、高齢の小規模世帯であり、年金世帯の割合 が高いなどそれほど経済的余裕がある階層ではなかったことが明ら かになった。また、震災前の住宅は小規模宅地で、年龄的にも、敷 地などの物理的条件から見ても、自己再建が事実上困難であった世 帯であったと考えられる。公団による震災復興共同建替事業は、そ のような世帯に対して、住み慣れた地域でコミュニティを維持しな がら、自己所有の住宅を供給した点で一定の役割を果たしたと考え られる。

しかし、入居後数年を経て生活が一旦落ち着いた現時点では、世 帯の高齢化が一層進んでいることもあり、将来の健康や生活の不安 が課題になっている。事業終了後、現時点では、震災復興共同建替 事業による住宅は、高龄世帯が多い分、一般の共同住宅よりも高齢 者の問題が顕著になる可能性を抱えている。今後の生活サポートや 住宅の維持管理をどうサポートしていくのかが課題であると言える。 2）事業参加世帯の約 7 割は、事業参加によって、震災前加の近 所付き合いを継続できたことが明らかになった。事業参加世帯は、 事業参加したこと自体には概ね満足しているが、住宅に対する満足 度が低い傾向がみられた。当事業では、戸別設計方式を取り入れて いたが、自分の思いどおりに設計をしてもらえたかなど、参加世帯 の住宅設計への関わり具合が事業参加満足度に影響を与えているこ とが窥えた。

3）事業参加への満足度を資産面から検討した結果、従前土地の権 利変換率が高いほど事業参加満足度が向上する傾向がみられた。現 時点では、事業参加世帯は様々な要素から、事業へ参加してよかっ たかどうかを評価しているが、資産の点では自らの居住する住宅の 価値を等価交換によって得られた面積の多塞で評価する一面がある のではないかと推察される。

4）事業参加の満足度は地区による違いが少なくないことが明らか になった。地区による事業の満足度の差異は、立地による権利変換 率の違いなど事業の経済的有利さの大小に加えて、個々の建物デザ インや敷地条件や周辺環境、設計者の対応の仕方などが反映されて いることが窥えた。

本研究で得られた知見は、公団が事業主体になって供給された、 震災復興という特殊な場面での共同建替事業の検討によるものであ る。しかしながら、一般の共同建替事業にもつながる事柄として、 (1)できあがった共同建替住宅は結果的に高齢者が多く集住すること になり、事業後は高龄世帯への生活サポートが求められていくこと、 (2)入居後、数年を経て落ちついた状態になった時期には、暮らして いる住宅そのものへの居住世帯の関心が高まり、住宅への満足度が 事業への満足度に転化すると思われることがあげられる。これらの 結果を、一般の既成密集市街地の共同建替事業につなげることにつ いては、別途取り組むべき研究課題である。

\section{謝辞}

本研究には、調査対象 7 地区の管理組合および多くの居住者の 方々にご協力いただいた。また、調查の実施は、大阪教育大学の学 生諸氏および神戸震災復興ボランティア“まちコミュニケーション” の協力によるところが大きい。ここに記して感謝の意を表します。 
注

注 1 ) 2000.1.17 阪神・淡路大鹿災神戸徉興誌(文献 20))によると、共同建替事 業は全部で 84 件である。そのうち公団関連の事業が 23 地区あるほか、神 戸市公社、民間等によっても事業が行われた。

注 2）以下の本文は、文献 1 ）に示す日本建築学会近幾支部研究報告集に発 粒した内容をもとに再検討し、加筆修正したものである。

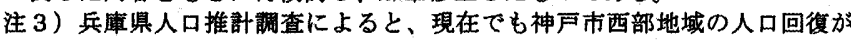
遅れている(文献 19))。

保留床処分にあたり神戸市西部地域が東部に比べ住宅需要圧が低く事業粠 筑が困難であったことは示されている（文城 11)20))。

注 4）参加申込書で分析した 7 地区の事業参加世带は102 世帯で、うち「従 前资産を持って参加した世带が 76 世带、従前資库を持たない世带が 26 世 农であった。一方、アンケート調查に回答した世带は、事業参加世帯が 77

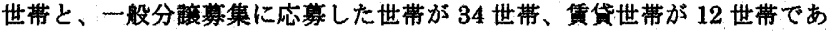
った。またアンケートに答えた事業参加世带のうち、従前資産を持って参 加した世带が 66 世带であった。

注 5 )残りの 約 $25 \%$ は、従前、当峐郡画地内には土地盗産を保有しないで 建替事業に参加した世带である。

注 6）神灭市復興誌（文献 20））によると、神灭市施行区面整理内の減歩率 は、狭小宅地については傾斜減歩方式が採用され、平均 $6 \%$ 減歩となって いる。本研究に㧍ける区画整理地内の従前土地面積は減歩後の土地面稓を 扱っている。震災前に居住していた住宅の土地面樻は減歩分を割り㞔して 考虑する必要がある。

注 7) 共同建替住宅の分䛨価格 3000 万円以上の世带には、自己居住用の住严 に加えて貸貸用の住戸を襀数戝入した世带を含んでいる。

注 8)図6の「なし」は、従前土地凟産の等価交換のみで共同建替住宅を取得 した世带と、追加鱼担額を全額現金一括で支払った世带を示す。本文の平 均値は「追加角担なし」の世带を除いた值である。

注 9）アンケート調查の回答は、事業参加世带が入居後 4〜 6 年を経て落ち 着いた生活を取り戻した状態で行なわれたものである。

注 10）アンケートに答えた事業参加世带は、77世带であるが、うち 1 世带 が资産や资金に関する回答を拒否したため、76 世带で集計している。

注 11）展災前からの近所付き合いが、同一共同建替住宅棟内で継続している 世龩は、事業参加の満足度について「たいへん不満が残る」と回答した世 带が 6.7\%であるのに対して、展災前からの付き合いが継繶していない世带

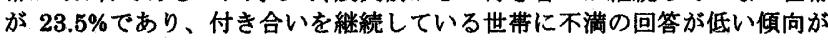
見られた。

「近所付き合いの継続なし」は、震災前も「付き合いなし」の世带も存在す る可能性が考えられる。

注 12）居住地に対して、「たいへん満足小、「まあ满足」と回答した世带は、 事業参加したことに対しても事業参加の渵足度で「たいへんよかった」「ま あよかった」の合計が $\mathbf{8 8 \%}$ であり、居住地に対して「やや不満」、「たい ん不満」と回答した世带は、事業参加の満足度で「たいいんよかった」「ま あよかった」の合計が 71\%を示している。

注 13）調查対象地区の事業すべてについて、䈉者が公団職員として担当した。 記载した事業経過などについては、担当者として居住世带に䦥き取り調查 を行った。

注 14)活用容積率は次の式で示す。活用容糟率=使用容積率／基準容積率

\section{参考文献}

1 ) 碓田智子、田中貢、伊藤奈々恵 : 事業参加世带からみた震災復興共同建 替住宅の評価に関する研究（その1）-事業参加世带の特性と入居の経緯に ついて・（その2）事業参加世帯からみた事業評価·日本建築学会近幾支部 研究報告集, pp.725・732, 2005

2）檽本清勇、東樋口護：展災街区における共同再建プロセスと専門家の役 割に関する調查研究、日本建築学会大会梗概集、pp.963·964,1997

3)木下明子，桑谷保弘，横川悟史，㙁崎㹂明 : 阪神・淡路大辰災の復興まち つくり組織の運営実態と合意形成過程に関する研究, 日本建築学会大会学 術講演梗概集, pp.325-326, 1998

4 )安田丑作，三輪康一，末包伸吾，富田裕介，松岛啓之：阪神・淡路大震災 の被災地におけるまちづくり組織の役割とその変化に関する研究（その 1) 一まちづくり組織における活動とその支援の変遷一，(その2）-まちづく り組織と今後のまちづくりのあり方 - , 日本建築学会大会学術講演梗概集, pp.147・150, 1999

$5)$ 安田丑作、三輸康一、末包伸吾、安田幸弘、岡田光輝：阪神·淡路大震災 の被災地における共同建替事業と、実現プロセスに関する研究一神戸市に おける事例調查を通じて（その 1)、（その2）日本建築学会学術講演会梗 概集, pp.447・450、2000

6) 藤田忍 : 阪神大震災の共同建替え事業におけるコンサルタントの役割、

日本建学会学術講演会梗概集, pp.371-373、2001

7）野沢千絵、小泉秀樹、大方潤一郎 : 震災復興における共同建替の実態と 地区環境の変化に関する研究, 第 35 回日本都市計画学会学術研究論文集 pp.409-414, 2000

8）鳥井口太一：土地区画整理事業地区における共同建替に関する研究，都 市住宅学秋季号 pp.184-188, 2001

9)安藤元夫、曾根秀一、小島孜 : 䒯屋西部地区のまちづくりプロセスにおけ
る計画案づくりの変愄に関する研究一「まちつくくり」型区画整理事業に向 けてのカウンタープランの意義と役割, 日本建築学会大会部画系論文集, pp.249-256, 2002

10）上身信之、安田丑作、三輸康一、末包伸吾 : 共闰建替におけるコミュニ ティ形成の実热とその形成要因に関する研究，日本建築学会大会学術講演 梗概集, pp.803-804, 2003

11）鈴木克彦、木多彩子：住宅共問再建による屒災復興とコミュニティ再生 (その1) (その 2), 日本マンション学会·学会誌第 21 量, pp.60-67, 2005

12）小林郁雄・神韯都市問題研究所 : 鹿災復興住宅の理論と実践一都市政策 論集 18 集, 勁草畫房, pp.110・140，1998.1

13）塩崎堅明、西川栄一、出口俊一：安藤元夫大震災 10 年と災害列島，ク リエイツかもがわ、,pp.121・123，2005.1

14）小野博保：都市政策第 97 号，神户都市問咸研究前、勁草書厉 pp36-38、 1999.1

15）阪神・淡路まちつくり支援機棈付属研究会 : 提票一大唇災に学ぶ住宅とま ちづくり，東方出版，pp.91-108，1999.3

16）神声市都市計画局 : 協㑬のまちづくりすまいつくく，2000.3

17）高寄昇三:阪神大震災と生活復興，勁草書鹿 pp.134*139，1999.9

18）安藤元夫：阪神・淡路大震災 : 復興都市計画事業・まちつくり，学芸出 版社, pp.232-264, 2004.2

19）兵庫県人口推計調查（2004 年 11 月 1 日現在）

20）神西市：阪神・淡路大震災，神正復興誌 pp.325-327，342-362，2000.1 (2005年10月 8 日原稿受理，2005年12月21日採用決定） 